\title{
EVIDENCE OF INTERPERSONAL VIOLENCE AT TWO SITES OF THE BIJELO BRDO CULTURE IN EASTERN CROATIA
}

\section{Željka Bedić}

Anthropological Centre

Croatian Academy of Sciences and Arts

Ante Kovačića 5

HR - 10000 Zagreb

zbedic@hazu.hr

UDK / UDC: UDK: 616.714.1-001.5:56(497.54)"653" Izvorni znanstveni rad / Original scientific paper https://doi.org/10.52064/vamz.54.1.21

Human skeletal remains from Bijelo Brdo-Venice Street and Vukovar-Lijeva Bara have previously been anthropologically analysed and published, but in this paper cranial traumas are studied for the first time. The sample consists of 84 adult skulls curated in the Natural History Museum and the Archaeological Museum in Zagreb. Results showed a high frequency of cranial trauma (19.0\%) recorded in 16 out of 84 well-preserved skulls.

\section{Key words:}

interpersonal violence, trauma, antemortem, perimortem, Bijelo Brdo culture Bijelo Brdo-Venice Street, Vukovar-Lijeva Bara

\section{Introduction}

Certain scientists agree that the manifestation and frequency of violence among humans is a result of their culture and enculturation within their environment, but it does not originate in their biology and genetics. ${ }^{1}$ The study of human skeletal remains with methods used in bioarchaeology, palaeopathology and forensic anthropology can reveal violent episodes and improve the understanding of violence in past populations. ${ }^{2}$
Although males exhibit twice as many traumas as females $(24.4 \%$ vs. $12.8 \%$ ) the difference is not statistically significant. Trauma is present most frequently on the left side of the skull, and there is perimortem trauma in both sites, as well as in both sexes; this indicates the existence of interpersonal violence in these populations.

Human skeletal remains from Bijelo Brdo-Venice Street (hereafter: Bijelo Brdo) and Vukovar-Lijeva Bara (hereafter: Vukovar) have already been anthropologically analysed and published. In her paper, Pilarić ${ }^{3}$ performed craniometric analysis on seven male and seven female skulls from the Bijelo Brdo cemetery Pilarić and Schwidetzky ${ }^{4}$ published the first multivariate statistical analysis, which included Bijelo Brdo and Vukovar among twelve medieval sites in the territory of the former Yugoslavia. 
Scientists from the School of Dental Medicine of the University of Zagreb, on a few occasions, have studied dental pathologies, estimated sex on the basis of tooth size, and analysed articular eminence inclination of the temporomandibular joint on osteological material, among which were samples from Bijelo Brdo. ${ }^{5}$

In a doctoral dissertation, these archaeological sites were anthropologically analysed together with other Bijelo Brdo culture cemeteries from the area between the rivers Sava, Drava and Danube, making one composite sample which was compared to Avaro-Slavic and Late Medieval samples. ${ }^{6}$

\section{Excavation of sites and archaeological features}

The archaeological site of Bijelo Brdo is located on the right bank of the Drava, about $16 \mathrm{~km}$ east of Osijek. The site is known for archaeological finds from the Bronze Age and two cemeteries from the Medieval Period: Avaro-Slavic (Bijelo Brdo-Bajer) and Bijelo Brdo culture (Bijelo Brdo-Venice Street). Archaeological excavations of the Bijelo Brdo cemetery started at the end of the $19^{\text {th }}$ century ${ }^{7}$ and lasted until $1907 .{ }^{8}$ The orientation of the skeletons in the graves was west-east, with the head to the west. ${ }^{9}$ Rich grave goods included earrings with a raceme pendant, S-circlets, necklaces twisted from one or more wires with glass beads and cowry shells, bracelets, rings, a crescent-shaped pendant, bells, buttons, a few knives and ceramic pots, and Árpád coins of kings Peter I (1044 - 1046), Andrew I (1046 - 1061) and Béla I (1060 - 1063). On the basis of the various finds, especially coins, the cemetery was dated to around 965 to approximately $1061 .{ }^{10}$

Excavations at the archaeological site of Vukovar were conducted from 1951 to 1953 under the guidance of employees of the Archaeological Museum in Zagreb: Marcel Gorenc, Zdenko Vinski and Ksenija Vinski-Gasparini.

The cemetery of Vukovar has not been fully explored, so it is not possible to tell how large it was. Almost all the skeletons were lying on their backs; only 4 skeletons have been found on their sides: two on the right side with extended legs (graves 43 and 85 ), and two on the left side with contracted legs (graves 60 and 307). The orientation of the deceased in the graves was west-east (head to the west) with varying degrees of deviation to the north and south. ${ }^{11}$ Grave goods were found in 191 graves, and jewellery was the most numerous item, represented by circlets, earrings, torques, necklaces, bracelets, rings and various pendants. Besides these, objects of everyday use were also found: knives, awls, needles, belt parts, weapons, military equipment, and ceramics. The cemetery in Vukovar is the oldest manifestation of this culture in Croatia, and the finds and material collected at the site have not been discovered anywhere else in Croatia. On the basis of the findings, the Vukovar cemetery is dated to the second half of the $10^{\text {th }}$ century and the early $11^{\text {th }}$ century. ${ }^{12}$

\section{Graves and osteological material}

In the Bijelo Brdo cemetery, altogether 236 graves have been excavated in five archaeological campaigns, and they can be divided into four successive phases. ${ }^{13}$

In Vukovar, 448 skeletons from 447 graves have been unearthed; nine of them were prehistoric, and the other 439 early-medieval. In addition, 101 prehistoric incinerated graves of the culture group of Dalj, the settlements of the Eneolithic Kostolac culture and Pannonian-Celtic Cornacates have been found. ${ }^{14}$ Osteological material during the excavations at the Vukovar site was collected and placed in bags. It was transported to the Archaeological Museum in Zagreb, but in 1955 it was removed to the Anthropological Institute of the Medical Faculty of the University of Zagreb so it "could be preserved, reconstructed and biostatistically processed." ${ }^{15}$ Pilarić and Schwidetzky ${ }^{16}$ state that the osteological material from Vukovar is composed of at least 101 male and 57 female skeletons, mostly from the Early Medieval period, and fewer from the Prehistoric.

As the traumas from these two sites have not yet been fully investigated, this study aims to analyse the adult sample from the Bijelo Brdo and Vukovar sites to describe in more detail the distribution and frequency of trauma in skulls and try to explain their aetiology.

\section{Material and methods}

From Bijelo Brdo, 89 skulls ( 36 male, 39 female and 14 subadult) were available for the anthropological analysis. Six skulls are stored in the Croatian Natural History Museum, while the others are kept in the Archaeological Museum in Zagreb. ${ }^{17}$

For the anthropological analysis from the Vukovar cemetery, 160 skeletons were available ( 85 male, 60 female and 15 subadult); however, for this study the sample was much smaller, because only skeletons with skulls were included. Thus 31 skulls (19 male, 6 female and 6 subadult) were analysed for the presence of trauma. Osteological material (mainly long bones and a few skulls) from Vukovar is stored in the Institute for Quaternary Palaeontology and Geology of the Croatian Academy of Sciences and Arts, while 18 skulls are curated in the Croatian Natural History Museum.

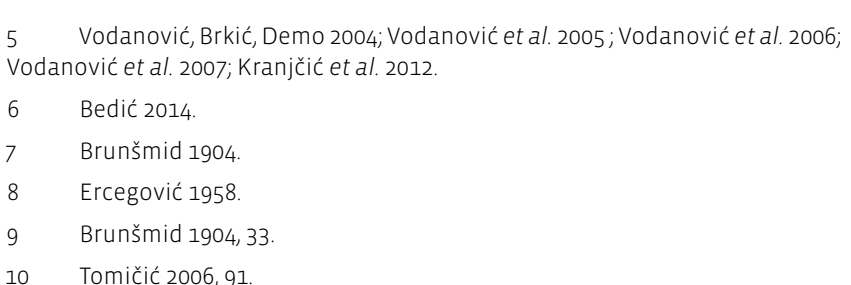

\author{
Demo 2009, 389, 396. \\ Demo 2009, 16. \\ Tomičić 2006, 91. \\ Demo 1996, 28-32. \\ Demo 2009, 21. \\ Pilarić, Schwidetzky 1987, 3-5
}




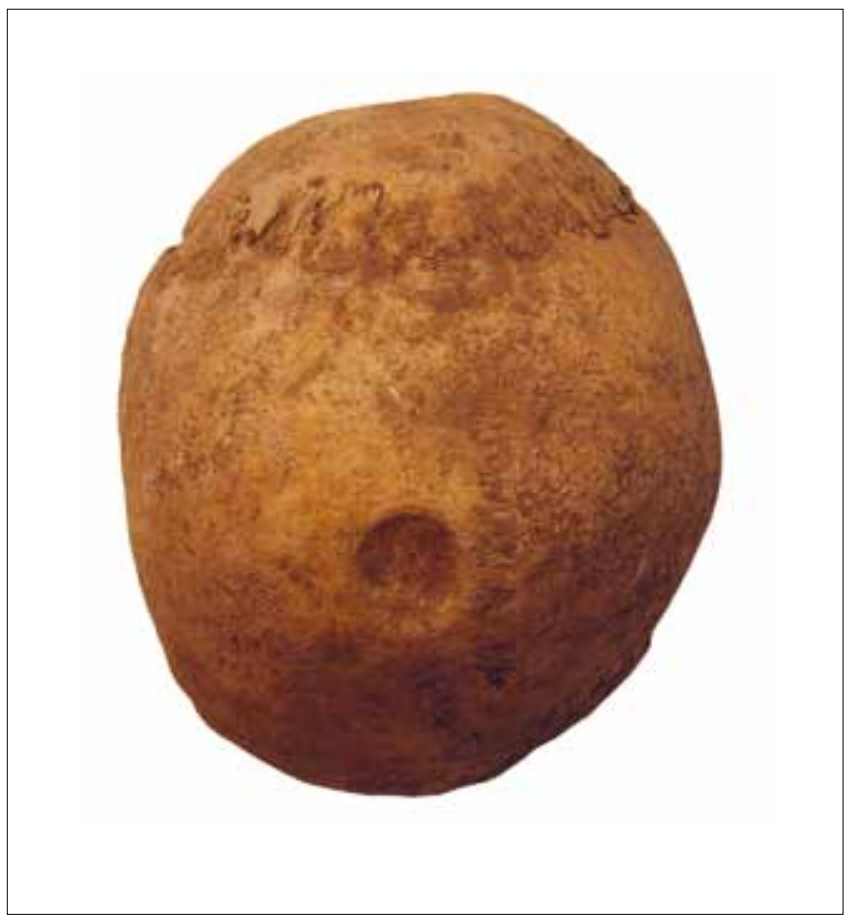

FIGURE 1. Massive depressed fracture on the right parietal bone in a male from grave 142 of the Bijelo Brdo site (photo by S. Latinović).

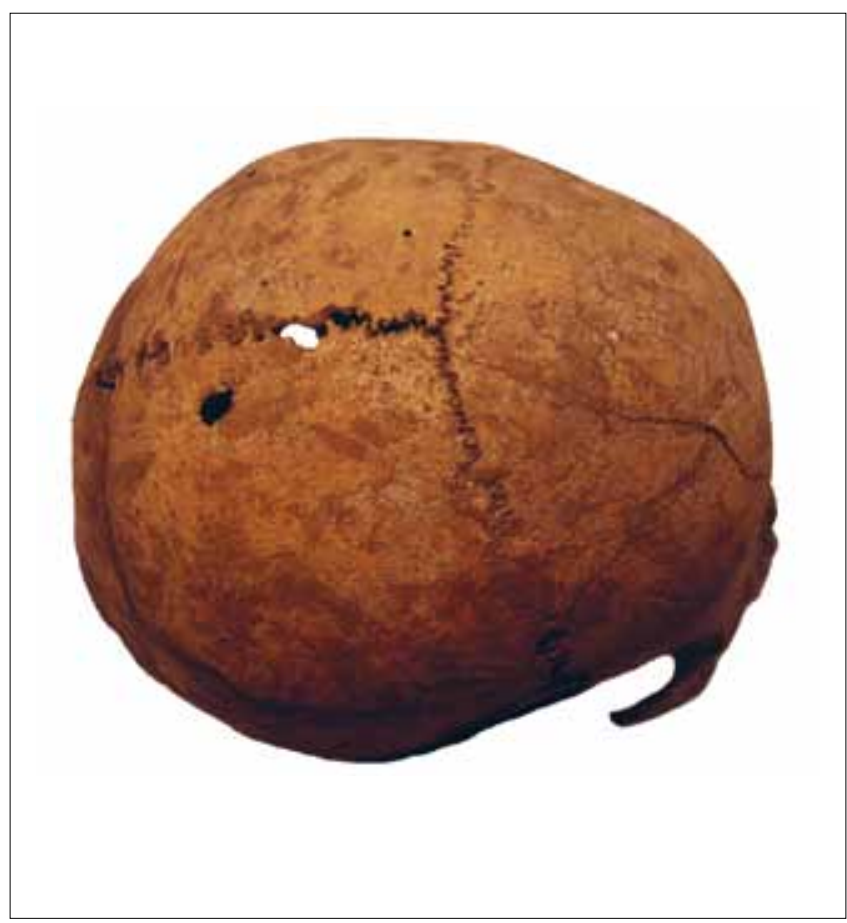

FIGURE 2. Perimortem trauma on the right parietal bone in a male from grave 169 of the Bijelo Brdo site (photo by S. Latinović)
Since mostly skulls were available for the study, sex and age were estimated on the basis of cranial features. For determining sex, the sharpness of the supraorbital margin, the prominence of the glabella, the size of the mastoid process and the robustness of the nuchal crest were used. ${ }^{18}$ Age was estimated according to cranial suture closure ${ }^{19}$ and dental attrition criteria established by Brothwell and Smith. ${ }^{20}$

Subadults, below 15 years of age, were excluded from the analysis, because bioarchaeological studies have indicated that children represent a low percentage of trauma ${ }^{21}$ and, in the sample studied, injuries were not documented in subadults.

Traumatic injuries are divided, on the basis of time of occurrence, into antemortem and perimortem traumas. Antemortem trauma happens before death and is characterized by healing and remodelling. ${ }^{22}$ Perimortem trauma occurs at or near the time of death and is recognized by the consistent colouring between the fracture surface and surrounding bone; ${ }^{23}$ there is no sign of healing, ${ }^{24}$ the edges of the fracture are well defined and sharp, ${ }^{25}$ and the fracture surface is flat or polished with macroscopically visible striation marks. ${ }^{26}$

Blunt-force traumas are recognized by the existence of plastic deformation, radiating fractures spreading from an impact site, or concentric fractures exhibiting an internal bevel. ${ }^{27}$ They usually occur during falls or through contact with blunt instruments. ${ }^{28}$ Penetrating injuries usually show internal and external bevelling. ${ }^{29}$ When partial, penetrating injuries have depressed, comminuted fractures caused by the crushing of bone at the impact site..$^{30}$ Linear lesions of sharp-force traumas are identified by the occurrence of well-defined sharp edges that have smooth, flat and polished cut surfaces. These lesions exhibit a V-shaped groove and parallel striations perpendicular to the kerf floor. ${ }^{31}$

\footnotetext{
17 Part of the osteological material from the Bijelo Brdo and Vukovar sites was analysed with prior approval in the Croatian Natural History Museum in Zagreb and the Archaeological Museum in Zagreb, where it is curated.

18 Buikstra, Ubelaker 1994, 19, 20.

19 Meindl et al. 1985

20 Brothwell 1981; Smith 1984

21 Judd 2004, 35; Šlaus 2008, 461; Scott, Buckley 2010, 511

22 Aufderheide, Rodríguez-Martín 1998.
}

Ubelaker, Adams 1995.

Sauer 1998.

Wheatley 2008.

Wakely 1997.

Berryman, Symes 1998.

Galloway et al. 1999.

Berryman, Symes 1998.

Milner, Anderson, Smith 1991

Houck 1998; Reichs 1998; Symes, Berryman, Smith 1998. 


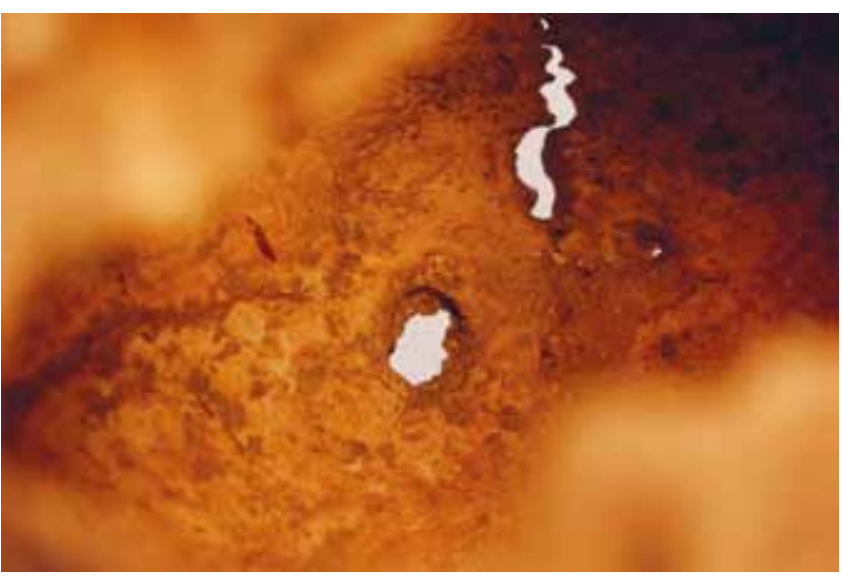

FIGURE 3. Perimortem trauma on the right parietal bone in the male from grave 169 of the Bijelo Brdo site: endocranial view (photo by S. Latinović)

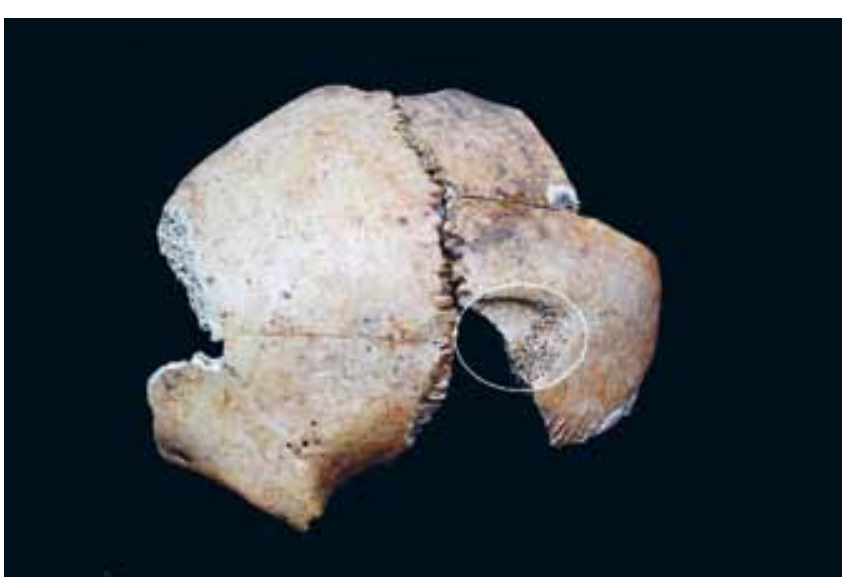

FIGURE 4. Perimortem trauma on the left parietal bone in a female from grave 60 of the Vukovar-Lijeva Bara site (photo by V. Vyroubal).

\section{Results}

Sixty well-preserved skulls ( 27 males and 33 females) from the Bijelo Brdo site, as well as 24 skulls ( 18 males and 6 females) from Vukovar were included in this study. Also, 20 subadult skulls from both sites were excluded for the above-mentioned reason.

Males at both sites had similar average ages at death (Bijelo Brdo 37 years; Vukovar 37.5 years) as well as females (Bijelo Brdo 30.4 years; Vukovar 29.5 years). The ratio of males to females and subadults in the Bijelo Brdo sample is $0.9: 1: 0.4$, while in the Vukovar sample it is $1: 0.7: 0.2$.

In the sample from Bijelo Brdo, 9 traumas were recorded in 60 skulls ( $15.0 \%$ ): $25.9 \%$ in males (7/27), and $6.1 \%$ in females (2/33). Altogether 12 cranial traumas were present, because three individuals exhibited two traumas on the skull.

The frequency of trauma in the Vukovar sample was $29.2 \%(7 / 24)$; $22.2 \%$ in males (4/18), and $50.0 \%(3 / 6)$ in females. Only two females had two traumas on the skull, giving a total number of 9 traumas in 24 skulls.

The trauma frequency in males is similar at both sites, while in females from Vukovar the trauma frequency was higher than in females from Bijelo Brdo.

In the two Bijelo Brdo sites, traumas were recorded in 16 of 84 well-preserved skulls (19.0\%). In females, trauma was present in $12.8 \%$ of the skulls (5/39), and in males in $24.4 \%$ (11/45). The difference in the frequency of trauma between females and males was not statistically significant $\left(\chi^{2}=1.831 ; p=0.17\right)$. A total of 21 cranial traumas were present in the sample: one trauma was present in 11 skulls, and two traumas were present in five skulls. The incidence of adults with multiple head traumas in the composite Bijelo Brdo sample is $31.3 \%$ (5/16). On the left side of the skull 13 traumas were recorded, while on the right side 8 traumas.
The frequency and distribution of the cranial traumas are shown in Table 1. The highest number of traumas in the sample analysed was present on the left parietal bone $(38.1 \%$, or $8 / 21$ ), the right parietal bone following with 6 traumas $(28.6 \%)$ and 5 traumas on the frontal bone, while only one trauma ( $4.8 \%$ ) was present on the right temporal bone and the facial skull. In the females, half of the traumas were recorded on the left parietal bone (4/8). In the males, the highest number of traumas was recorded on the right parietal bone (5/13, or $38.5 \%)$, followed by the left parietal bone (4/13, or $30.8 \%)$.

Out of a total of 21 cranial traumas, 16 antemortem traumas were present, and most of them were well-healed oval or elongated depressed fractures. Twelve antemortem traumas were recorded in males, and four in females. These traumas were most likely caused by blunt objects. An example of this type of trauma is a massive depressed fracture present on the skull of the individual from grave 142 of the Bijelo Brdo site. A male aged between 36 and 45 years had a fracture measuring $26 \times 22 \mathrm{~mm}$ and approximately $0.5 \mathrm{~cm}$ deep on the right parietal bone (Fig. 1) with rounded edges and a porous bottom. On the endocranial (inner) side, the wall of the skull is slightly convex.

In one case only, the depressed fracture manifested healed, wellremodelled fracture lines. The trauma was on the right temporal bone of a male aged 40 to 55 years from grave 176 of the Vukovar site. The first horizontal line of the fracture, $41 \mathrm{~mm}$ long, follows the zygomatic arch, while the second is perpendicular to the first, $10 \mathrm{~mm}$ superior to it. The inferior edge had an opening with rounded edges, which suggests that the blow penetrated the wall of the skull.

A total of five perimortem traumas were present on one male and three females. 


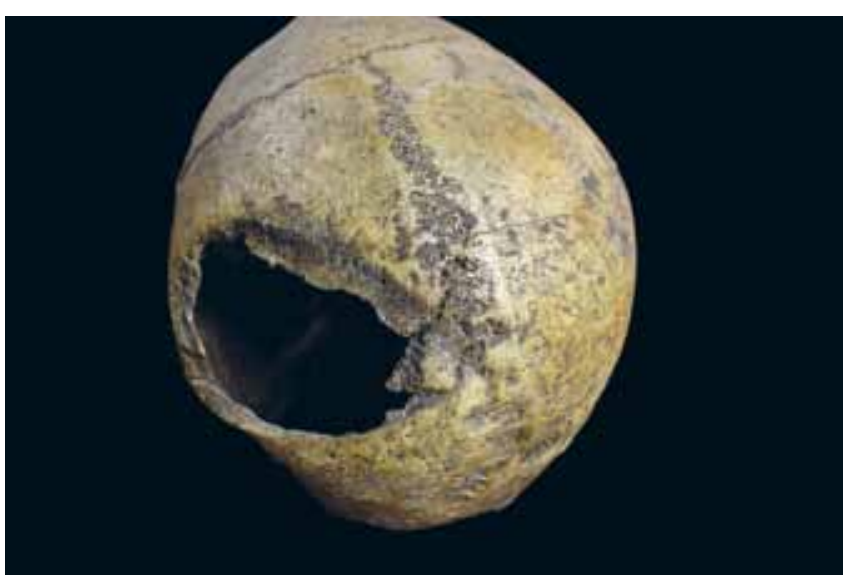

FIGURE 5. Perimortem trauma on the left parietal bone in a female from grave 68 of the Vukovar-Lijeva Bara site (photo by V. Vyroubal).

One in 11 males with cranial trauma had one perimortem trauma $(9.1 \%)$, i.e. the frequency of perimortem traumas in the total number of cranial traumas in males is $7.7 \%(1 / 13)$.

This perimortem trauma of the male is from grave 169 of the Bijelo Brdo site. It is an irregularly-shaped trauma measuring 9 $\times 7 \mathrm{~mm}$, located on the right parietal bone (Fig. 2). The edges of the defect are the same colour as the surrounding bone. Internal bevelling with edges is of the the same colour as the surrounding bone (Fig. 3). The trauma is probably the result of a penetrating object.

One female had two perimortem traumas; therefore the incidence of perimortem trauma in the total number of cranial traumas in females was $50 \%$ (4/8). One trauma is present on the frontal bone, and two on the right parietal bone, while one is present on the left side of the facial skull. All three females with recorded perimortem trauma were from the Vukovar site. A 15 - 18-yearold female from grave 60 had a perimortem incision on her left parietal bone (Fig. 4). The incision is tangential (it did not penetrate the wall of the skull), measuring $45 \times 25 \mathrm{~mm}$ (part of the bone is missing postmortem), and has sharp edges without signs of healing. The trauma was most probably caused by a sharp object.

On the skull of a female aged between 30 and 40 years from grave 68 , a massive perimortem incision that penetrated the wall of the skull was documented (Fig. 5). The incision was located on the left parietal bone, and its initial incision (the place where the blade enters the bone), $75 \mathrm{~mm}$ long, is polished and without signs of healing. The part of the bone superior to the incision is completely missing, because it was probably dislodged during the extraction of the blade from the bone. However, this edge of the wound shows some signs of healing recognized by new bone formation, suggesting that the female lived for a short period of time. The trauma was caused by a sharp-edged object.

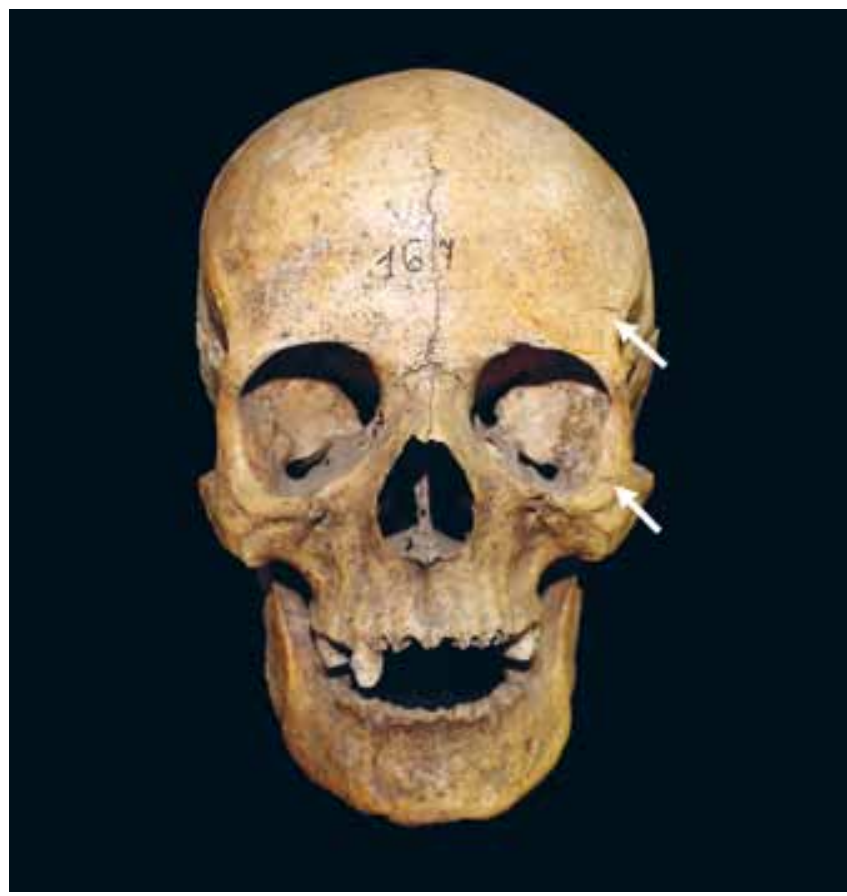

FIGURE 6. Perimortem trauma on the left side of the frontal bone and left zygomatic bone in a female from grave 167 of the Vukovar-Lijeva Bara site (photo by $\mathrm{V}$. Vyroubal).

A 20 - 30-year-old female from grave 167 had two perimortem in cisions at the time of death. The first was located on the left side of the frontal bone, $15 \mathrm{~mm}$ superior to the superior edge of the left orbit. The initial incision is superior, $13 \mathrm{~mm}$ long, and sharp (Fig. 6). The second incision is parallel to the first and is located $42 \mathrm{~mm}$ inferiorly on the left zygomatic bone (Fig. 7). It is $15 \mathrm{~mm}$ long, with a sharp edge without traces of healing. Both traumas were inflicted by a sharp-edged object.

\section{Discussion}

Average age at death in males from Bijelo Brdo and Vukovar (37 and 37.5 years) is similar to the recorded age in the composite Bijelo Brdo sample (36.6 years); 32 however, females from Bijelo Brdo and Vukovar (30.4 and 29.5 years) lived somewhat shorter than the composite sample (35.5 years). ${ }^{33}$ The difference between the Bijelo Brdo and composite Bijelo Brdo samples was statistically significant $\left(\chi^{2}=5.434 ; p=0.020\right)$, while the difference between Vukovar and composite Bijelo Brdo was not $\left(\chi^{2}=0.000 ; p=\right.$ 1), probably due to the small Vukovar sample. ${ }^{34}$ At this moment it is not possible to explain the difference.

\footnotetext{
32 Bedić 2014, 78.

33 Bedić 2014, 78.

34 The Kruskal-Wallis Test was used for calculating the statistical differen-
} 


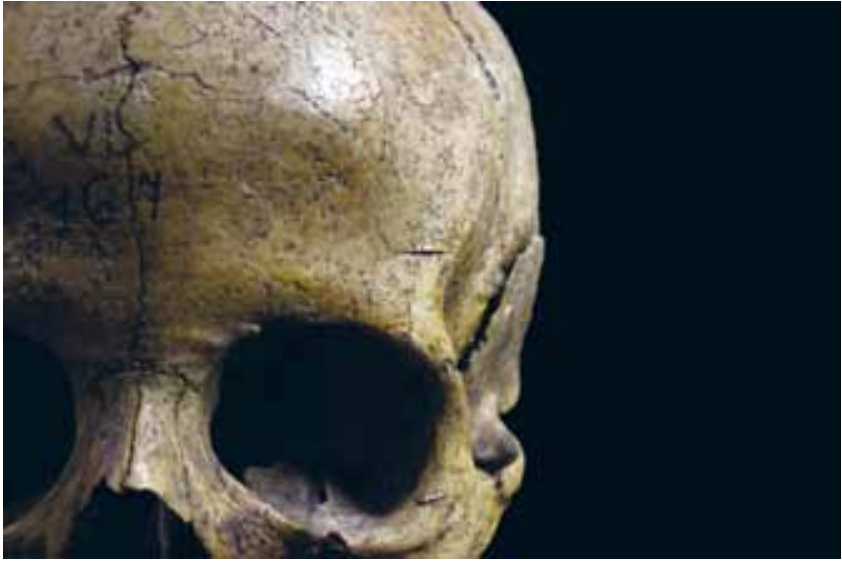

FIGURE 7. Deatil of the perimortem trauma on the left side of the frontal bone and left zygomatic bone in the female from grave 167 of the Vukovar-Lijeva Bara site (photo by V. Vyroubal).

The sex distribution for skeletons analysed in the Bijelo Brdo sample is similar to most medieval samples in Croatia, which usually include similar numbers of males and females, and a relatively smaller number of subadults. ${ }^{35}$ The Vukovar cemetery shows moderate underrepresentation of females. Subadults are underrepresented in both samples; however, it must be emphasized that, according to the photographs and drawings at the Vukovar site, the presence of 134 subadult skeletons was established, which would correspond to $30.5 \%$ of the total number of skeletons from this site. ${ }^{36}$ Although only a small part of the osteological material from the excavated cemeteries was available for the study, sex and age distribution in both sites appears to be more or less normal.

The high frequency of cranial trauma in a particular population indisputably suggests the presence of intentional interpersonal violence. ${ }^{37}$ The incidence of cranial trauma in archaeological populations from different parts of the world ranges from about $2 \%$ to $10 \% .{ }^{38}$ Therefore, the very high frequencies of these injuries at the two sites analysed are indicative of an increased amount of violence. Bijelo Brdo and Vukovar are only 30 kilometres apart, and they are dated to the same period. Vukovar is dated to the second half of the $10^{\text {th }}$ century and the early $11^{\text {th }}$, while Bijelo Brdo is dated from 965 to $1061 .{ }^{39}$ Although this is a relatively short period of about 100 years, it is not possible to say which violent episode it was. Among the scarce historical sources for that period, only an anonymous notary of King Bela appears, who brings the news that Hungarian military leaders, while returning from one of their plundering raids, occupied the castra of Zabrag (Zagreb), Posaga (Požega) and Vlcou (Vukovo) in the $10^{\text {th }}$ century. $4^{0}$ However, on the basis only of that, this historical source cannot be connected with the perimortem traumas in Bijelo Brdo and Vukovar. According to Goldstein, ${ }^{41}$ the Hungarians at that time were still engaged in cattle breeding and looting of the surrounding areas, so theoretically there could have been frequent attacks on these areas along the Drava and Danube. Also, it could be endemic violence between various smaller settlements relating to disputes over land or water sources. In this context, the sexual distribution of the trauma - towards three women and only one man indicates low-intensity violence (disputes or quarrels over land or looting raids) more likely than it would suggest some kind of military conflict. A similar situation was recorded at the Late Medieval sites of Crkvari and Kliškovac, where, out of a total of 6 individuals with perimortem trauma, no fewer than four were females. ${ }^{42}$

Also, the location inside the cemetery of the three killed women should be taken into account. Demo notes that the Bijelo Brdo culture cemetery in Vukovar originated from several initial positions recognizable by graves with weapons or weapons and military equipment, as the probable first sites of burial. Later they expanded more or less radially from the centre outwards, overlapping with one of the neighbouring zones..$^{43}$ In this context it is interesting to take a look at the plan of the cemetery ${ }^{44}$ and the arrangement of the female graves with perimortem injuries. Grave 60 is situated near grave 336, which is in zone I, while graves 68 and 167 are near grave 127, in zone III. This would mean that these graves belonged to the earlier period of utilization of the Vukovar cemetery, at the beginning of the second half and the end of the second third of the $10^{\text {th }}$ century. ${ }^{45}$

The distribution of cranial traumas by bone element shows that the left parietal bone was the most frequently affected part of the skull, followed by the right parietal and frontal bones. Most of the cranial traumas in the sample are located on the left side, which has previously been seen in numerous studies. ${ }^{46}$ In face-toface combat, the left side of the skull is the most frequent injury site, as the attackers are, in most cases, right-handed.

\footnotetext{
35 Šlaus 2002, 98.

36 Demo 2009, 389

37 Alvrus 1999; Standen, Ariazza 2000; Tyson 1977; Walker 1989; 1997.

38 Bennike 1985; Ferguson 1980; Jurmain 2001; Morse 1969; Owsley, Gill, Owsley 1994; Robb 1997; Stewart, Quade 1969.
}

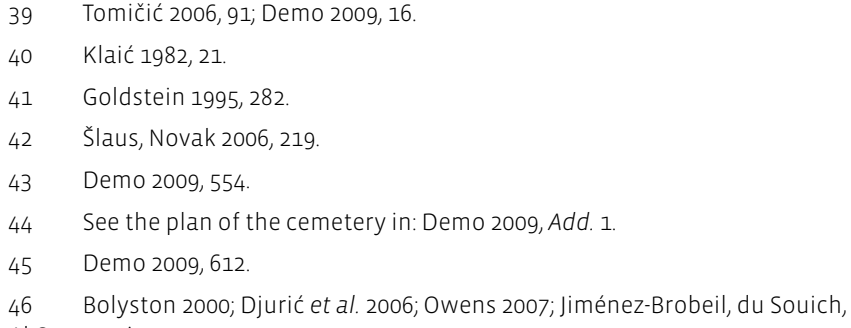
Al Oumaoui 2009. 


\begin{tabular}{|c|c|c|c|c|c|}
\hline Sex & \multicolumn{2}{|c|}{ Males } & \multicolumn{2}{|c|}{ Females } & \multirow{2}{*}{ Tota } \\
\hline Bone element & $\mathrm{AM}^{*}$ & PM & $\mathrm{AM}$ & PM & \\
\hline Frontal & 3 & & 1 & 1 & 5 \\
\hline Left parietal & 4 & & 2 & 2 & 8 \\
\hline Right parietal & 4 & 1 & 1 & & 6 \\
\hline Occipital & & & & & 0 \\
\hline Left temporal & & & & & 0 \\
\hline Right temporal & 1 & & & & 1 \\
\hline Face & & & & 1 & 1 \\
\hline Total & 12 & 1 & 4 & 4 & 21 \\
\hline
\end{tabular}

TABLE 1. The frequency and distribution of cranial fractures in the Bijelo Brdo and Vukovar-Lijeva Bara sample (made by Ž. Bedić). *AM - antemortem fracture; PM - perimortem fracture

The high frequency of cranial injuries evidenced also on the right side may suggest that the injuries were received while the victims were running away from their attacker or while they were lying prone. ${ }^{47}$

Of the 21 cranial traumas, 16 traumas were well-healed depressed fractures, for which it is impossible to say what kind of weapon caused them, except that it was a blunt object.

Traumas also differ by the weapon with which they were inflicted. Heavy and hard objects cause depressed (crush) fractures, while pointed and edged objects (knives, swords) produce penetrating injuries and cuts..$^{48}$

It also cannot be told by what weapon the male from grave 169 was killed, except that it was a penetrating injury. A spear and an arrow come into consideration, and since it is a very small wound, $9 \times 7 \mathrm{~mm}$, it would more likely be an arrow. Three females had incisions, two of them being incisions of sizeable dimensions, so it could have been a sword or a sabre, while the third female had two small incisions, suggesting that the weapon could have been a knife.

It is worth mentioning that weapons and military equipment were found in the Vukovar cemetery. However, these items (arrows, quivers and one reflex bow) are the rarest and least numerous group of objects in the grave inventory. ${ }^{49}$ Arrows were the most numerous among them (22) but it is impossible to connect the projectile injury in the male from grave 169 of the Bijelo Brdo site with this kind of weapon. Also, objects of everyday use were discovered in the graves, with knives representing the dominant object ( $37.1 \%) . .^{50}$ One incision to the left side of the frontal bone and one to the left zygomatic bone in the female from grave 167 of the Vukovar site were probably inflicted by a knife. Since knives, as items of military equipment, were not found in the graves, the question is whether knives for everyday use could have served as the weapon. Sharp-bladed weapons, such as swords, sabres or battle knives, were not found in the graves, so it remains unknown what kind of weapons injured the two females from graves 60 and 68. It does not mean that such weapons did not exist and were not in use by the population of that time.

Among the hunting and fishing gear, two clay projectiles for slings were unearthed. Because of their small dimensions (2.47 and $3.32 \mathrm{~cm}$ ) and not very great weight (no more than $35 \mathrm{~g}$ ), Demo $^{51}$ (2009) thinks they were used for hunting birds and small animals. However, the dimensions of the sling shot resemble the dimensions of the depressed antemortem fracture $(2.6 \times 2.2 \mathrm{~cm})$ in the male from grave 142 of the Bijelo Brdo cemetery. Possibly similar kinds of objects could have produced this type of injury.

The above-mentioned skeleton of a female with perimortem trauma to the skull from grave 60 of the Vukovar site was buried
47 Larsen 1999.

48 Lovell 1997.

49 Demo 2009, 424
50 Demo 2009, 610.

51 Demo 2009, 421. 
in an unusual position. The deceased was lying on her left side with her legs bent and her head turned to the left (towards the north). The left forearm is bent upwards with the fist under the mouth and the right upward with the fist on the upper arm of the left hand. A circlet, two bronze rings and fragments of a medieval pot were found in her grave..$^{52}$ According to Szabó's typology of unusual burial position, this is type II.2a,53 i.e. position on the left side with contracted legs. She is the only one among the skeletons with perimortem trauma who was buried with grave goods. It is possibly due to the circumstances of her death, although she did not differ from other members of the community during her lifetime, that the female with a perimortem incision on the skull from grave 60 was buried unusually. She was probably the victim of a murder; and, according to folk beliefs, a violent and premature death placed this woman in the category of possible restless dead or vampires. ${ }^{54}$ In Gdańsk, during the archaeological excavations at the Hala Targova site, three graves containing skeletons buried on their backs or sides with contracted legs were found. They are dated between AD 1227 and the middle of the $14^{\text {th }}$ century, while their unusual burial rite in the grave is associated with the violent death of the deceased. ${ }^{55}$ These burials are often interpreted as a consequence of a fear of the return of the dead, and generally have a negative connotation. ${ }^{56}$

\footnotetext{
52 Demo, 2009, 84

53 Szabó 1976, 39.

54 Unger 2006, 164

55 Krzywdziński 2006, 122, 125, 132.

56 Kovrig 1963
}

In conclusion, the results of this analysis show that a high number ( $19 \%$ ) of cranial traumas, especially perimortem ones (7.7\%), and their distribution on the skull, where the left parietal bone is the most commonly-affected location, testify to the existence of interpersonal violence in the populations that were buried in the Bijelo Brdo and Vukovar sites. The high frequency of traumas in females, where half of them were perimortem, suggests that this was the result not of military conflict, but rather of low-intensity violence like that of looting raids. Because of the lack of historical sources, it is impossible to say which exact episodes of violence those were. Although some of the objects were found as items of weaponry and military equipment (arrows, quivers and one reflex bow) and objects of everyday use (knives) in the graves from Vukovar, they cannot be attributed as the types of weapon by which individuals were killed in these two sites.

Further archaeological and anthropological research on the populations of the Bijelo Brdo culture is needed in order to clarify the high incidence of interpersonal violence. 


\section{BIBLIOGRAPHY}

Alvrus 1999 - A. Alvrus, Fracture Patterns Among the Nubians of Semna South, Sudanese Nubia, International Journal of Osteoarchaeology 9, 1999, 417-429.

Aufderheide, Rodríguez-Martín 1998 - A. C. Aufderheide, C. Rodríguez-Martín The Cambridge Encyclopedia of Human Paleopathology, Cambridge University Press, 1998.

Bedić 2014 - Ž. Bedić, Antropološka analiza osteološke građe bjelobrdskih pop ulacija u međurječju Save, Dunava i Drave, unpublished PhD thesis, Sveučilište u Zadru, 2014

Bennike 1985 - P. Bennike, Paleopathology of Danish Skeletons: A Comparative Study of Demography, Disease and Injury, Akademisk Forlag, 1985.

Berryman, Symes 1998 - H. E. Berryman, S. A. Symes, Recognizing gunshot and blunt cranial trauma through fracture interpretation, in Reichs, K. J. (ed.), Forensic osteology: advances in the identification of human remains, Charles C. Thomas, 1998, 333-352.

Bolyston 2000 - A. Boylston, Evidence for weapon related trauma in British archaeological samples, in Cox M., Mays S. (eds.), Human osteology in archaeology and forensic medicine, Greenwich Medical Media, 2000, 357-380

Brothwell 1981 - D. R. Brothwell, Digging Up Bones, Oxford University Press, 1981.

Brunšmid 1904 - J. Brunšmid, Hrvatske sredovječne starine, Viestnik hrvatskoga Arkeologičkoga društva, 1904, 30-97.

Buikstra, Ubelaker 1994 - J. E. Buikstra, D. H. Ubelaker, Standards for Data Collection from Human Skeletal Remains, Fayetteville, 1994.

Demo 1996 - Ž. Demo, Vukovar - Lijeva bara, Arheološki muzej u Zagrebu, 1996.

Demo 2009 - Ž. Demo, Ranosrednjovjekovno groblje bjelobrdske kulture Vukovar-Lijeva Bara (X - XI. stoljeće) / An Early Medieval Cemetery of the Bijelo Brdo Culture: Vukovar-Lijeva Bara (10 $10^{\text {th }}-11^{\text {th }}$ Centuries), Musei Archaeologici Zagrabiensis Catalogi et Monographiae / Katalozi i monografije Arheološkog muzeja u Zagrebu 6/1-2, Arheološki muzej u Zagrebu, 2009.

Djurić et al. 2006 - M. P. Djurić, C. A. Roberts, Z. B. Rakočević, D. D. Djonić, A. R. Lešić,

Fractures in Late Medieval skeletal populations from Serbia, American Journal of Physical Anthropology 130, 167-178.

Ercegović 1958 - S. Ercegović, Neobjavljeni grobni nalazi iz Bijelog Brda, Starohrvatska prosvjeta 6, 1958, 165-186

Ferguson 1980 - C. Ferguson, Analysis of skeletal remains, in Cordel, L. S. (ed.) Tijeras Canyon: analysis of the past, University of New Mexico, 1980, 121-148.

Galloway et al. 1999 - A. Galloway, S. A. Symes, W. D. Haglund, D. L. France, The role of forensic anthropology in trauma analysis, in Galloway, A. (ed.), Broken bones: anthropological analysis of blunt force trauma, Charles C. Thomas, 1999 5-31.

Goldstein 1995 - I. Goldstein, Hrvatski rani srednji vijek, Zavod za hrvatsku povijest Filozofskog fakulteta Sveučilišta u Zagrebu, 1995

Houck 1998 - M. H. Houck, Skeletal trauma and the individualization of knife marks in bone, in Reichs, K. J. (ed.), Forensic osteology. Advances in the identification of human remains, Charles C. Thomas, 1998, 410-424

Jiménez-Brobeil, du Souich, Al Oumaoui 2009 - S. A. Jiménez-Brobeil, P. du Souich, I. Al Oumaoui, Possible relationship of cranial traumatic injuries with violence in the south-east Iberian Peninsula from the Neolithic to the Bronze Age, American Journal of Physical Anthropology 140, 2009, 465-475.

Judd 2004 - M. Judd, Trauma in the City of Kerma: Ancient versus Modern Injury Patterns, International Journal of Osteoarchaeology 14, 2004, 34-51.

Jurmain 2001 - R.D. Jurmain, Paleoepidemiological patterns of trauma in a prehistoric population from central California, American Journal of Physical Anthropology 115, 2001, 13-23.
Klaić 1982 - N. Klaić, Zagreb u srednjem vijeku, Sveučilišna naklada Liber, 1982 Kovrig 1963 - I. Kovrig, Das awarenzeitliche Graberfeld von Alattyan, Archaeologica Hungarica 40, Akademiai Kiadó, 1963.

Kranjčić et al. 2012 - J. Kranjčić, D. Vojvodić, D. Žabarović, M. Vodanović, D. Komar, K. Mehulić, Differences in articular-eminence inclination between Medieval and contemporary human populations, Archives of oral biology 57, 2012, 1147-1152.

Krzywdziński 2006 - R. Krzywdziński, Katalog pochówków ze stanowiska 5 - Hala Targowa w Gdańsku od połowy XII wieku do 1813 roku, Archeologia Gdańska 2, 2006, 65-174

Larsen 1999 - C. S. Larsen, Bioarchaeology: interpreting behavior from the human skeleton, Cambridge University Press, 1999

Lovell 1997 - N. Lovell, Trauma Analysis in Paleopathology, Yearbook of physical anthropology 40, 1997, 129-170.

Martin, Harrod 2012 - D. L. Martin, R. P. Harrod, Body parts and parts of bodies: traces of violence in past cultures, International Journal of Paleopathology 2 2012, 49-52.

Martin, Harrod 2015 - D. L. Martin, R. P. Harrod, Bioarchaeological contribu tions to the study of violence, American Journal of Physical Anthropology 156, 2015, 116-145.

Meindl et al. 1985 - R. S. Meindl, C. O. Lovejoy, R. P. Mensforth, L. Don Carlos, Accuracy and direction of error in the sexing of the skeleton: Implications for paleodemography, American Journal of Physical Anthropology 68, 1985, 79-85.

Milner, Anderson, Smith 1991 - G.R. Milner, E. Anderson, V.G.Smith, Warfare in late prehistoric west-central Illinois, American Antiquity 56, 1991, 581-603.

Morse 1969 - D. Morse, Ancient diseases in the Midwest, Illinois State Museum, 1969.

Owens 2007 - L. Owens, Craniofacial trauma in the Prehispanic Canary Islands International Journal of Osteoarchaeology 17, 2007, 465-478

Owsley, Gill, Owsley 1994 - D. W. Owsley, G. W. Gill, S. D. Owsley, Biological ef fects of European contact on Easter Island, in Larsen, C. S., Milner, G. R. (eds.) Biological responses to conquest, Wiley - Liss, 1994, 161-177.

Pilarić 1968 - G. Pilarić, Fenotipske značajke bjelobrdskih lubanja iz ranog srednjeg vijeka, Arheološki radovi i rasprave 6, 1968, 263-291.

Pilarić, Schwidetzky 1987 - G. Pilarić, I. Schwidetzky, Vukovar und Bribir: Beitrag zur Anthropologie mittelalterlicher Sudslawen, Homo 38/1, 1987, 1-15.

Reichs 1998 - K.J. Reichs, Postmortem dismemberment: recovery, analysis and interpretation, in: Reichs, K. J. (ed.), Forensic osteology. Advances in the identification of human remains, Charles C. Thomas, 1998, 353-388.

Robb 1997 - J. Robb, Violence and gender in early Italy, in Martin, D. W., Frayer D. L. (eds), Troubled times: Violence and Warfare in the Past (War and Society), Gordon and Breach, 1997, 77-109.

Sauer 1998 - N. Sauer, The timing of injuries and manner of death: Distinguishing among antemortem, perimortem, and postmortem trauma, in Reichs, K. J. (ed.), Forensic Osteology: Advances in the Identification of Human Remains, Charles C. Thomas, 1998, 321-332.

Scott, Buckley 2010 - R.M. Scott, H.R. Buckley, Biocultural interpretations of trauma in two prehistoric Pacific Island populations from Papua New Guinea and the Solomon Islands, American Journal of Physical Anthropology 142, 2010, 509-518.

Smith 1984 - B.H.Smith, Patterns of molar wear in hunter-gatherers and agriculturalists, American Journal of Physical Anthropology 63, 1984, 39-56.

Standen, Ariazza 2000 - V. G. Standen., B. T. Ariazza, Trauma in the Preceramic Coastal Populations of Northern Chile: Violence or Occupational Hazards? American Journal of Physical Anthropology 112, 2000, 239-249. 
Stewart, Quade 1969 - T. D. Stewart., L. G. Quade, Lesions of the frontal bone in American Indians, American Journal of Physical Anthropology 30, 1969, 89-110.

Sussman 2013 - R.W. Sussman, Why the legend of the killer ape never dies: the enduring power of cultural beliefs to distort our view of human nature, in Fry, D.P. (ed.), War, peace, and human nature: the convergence of evolutionary and cultural views, Oxford University Press, 2013, 97-111.

Symes, Berryman, Smith 1998 - S. A. Symes, H. E. Berryman, O. C. Smith, Saw marks in bone: introduction and examination of residual kerf contour, in Reichs, K. J. (ed.), Forensic osteology. Advances in the identification of human remains, Charles C. Thomas, 1998, 389-409.

Šlaus 2002 - M. Šlaus, The Bioarchaeology of Continental Croatia. An analysis of human skeletal remains from the prehistoric to post-medieval periods, Oxford: Archaeopress, BAR International Series 1021, 2002.

Šlaus 2008 - M. Šlaus, Osteological and dental markers of health in the transi tion from the Late Antique to the Early Medieval period in Croatia, American Journal of Physical Anthropology 136, 2008, 455-469.

Šlaus, Novak 2006 - M. Šlaus, M. Novak, Analiza trauma u srednjovjekovnim uzorcima iz Kliškovca i Crkvara, Prilozi instituta za arheologiju u Zagrebu 23, 2006, 213-228.

Tomičić 2006 - Ž. Tomičić, Bijelo Brdo, in Durman, A. (ed.), Stotinu hrvatskih arheoloških nalazišta, Leksikografski zavod Miroslav Krleža, 2006, 156-157.

Tyson 1977 - R. A. Tyson, Historical accounts as aids to physical anthropology. Examples of head injury in Baja California, Pacific Coast Archaeological Society Quarterly 13, 1977, 52-58.

Unger 2006 - J. Unger, Pohřební ritus 1. až 20. století v Evropě z antropologickoarcheologické perspektivy, Panorama biologicke a sociokulturni antropologie 25, Akademické nakladatelství CERM, 2006

Ubelaker, Adams 1995 - D. Ubelaker, B. Adams, Differentiation of perimortem and postmortem trauma using taphonamic indicators, Journal of Forensic Sciences 40, 1995, 509-512.
Vodanović, Brkić, Demo 2004 - M. Vodanović, H. Brkić, Ž. Demo, Paleostomatološka analiza humanoga kraniofacijalnoga osteološkoga materijala sa srednjevjekovnog nalazišta Bijelo Brdo kraj Osijeka, Vjesnik Arheološkog muzeja u Zagrebu 37, 2004, 251-261.

Vodanović et al. 2005 - M. Vodanović, H. Brkić, M. Šlaus, Ž. Demo, The frequency and distribution of caries in the mediaeval population of Bijelo Brdo in Croatia $\left(10^{\text {th }}-11^{\text {th }}\right.$ century), Archives of oral biology 50/77, 2005, 669-680.

Vodanović et al. 2006 - M. Vodanović, J. Dumančić Ž. Demo, D. Mihelić, Određivanje spola na temelju diskriminantne analize mandibula iz dva hrvatska arheološka nalazišta, Acta Stomatologica Croatica 40/3, 2006, 263-277.

Vodanović et al. 2007 - M. Vodanović, Ž. Demo, V. Njemirovskij, J. Keros, H. Brkić, Odontometrics: a useful method for sex determination in an archaeological skeletal population?, Journal of archaeological science 34/6,2007, 905-913.

Wakely 1997 - J. Wakely, Identification and analysis of violent and nonviolent head injuries in osteo-archaeological material, in Carman J. (ed.), Material harm: archaeological studies of war and violence, Cruithne Press, 1997, 24-46.

Walker 1989 - P.L. Walker, Cranial injuries as evidence of violence in prehistoric southern California, American Journal of Physical Anthropology 80,1989, 313-323.

Walker 1997 - P. L.Walker, Wife beating, boxing and broken noses: Skeletal evidence for the cultural patterning of violence, in Martin D., Frayer D. (eds.) Troubled times: Violence and Warfare in the Past (War and Society), Gordon and Breach, 1997,145-180.

Walker 2001 - P.L. Walker, A bioarchaeological perspective on the history of violence, Annual Review of Anthropology 30, 2001, 573-596.

Wheatley 2008 - B.P. Wheatley, Perimortem and postmortem bone fractures? An experimental study of fracture patterns in deer femora, Journal of Forensic Sciences 53/1, 2008, 69-72. 